\title{
Patterns of mortality in sickle cell disease in the United Kingdom
}

\author{
A Gray, E N Anionwu, S C Davies, M Brozovic
}

\begin{abstract}
Eighteen of 384 patients entered on the Brent sickle cell disease register died between 1974 and 1989, a mortality of one per 128 years of follow up. Two children died from acute splenic sequestration and a third died from fulminant pneumococcal septicaemia: none was taking prophylactic penicillin. Acute chest syndrome was the cause of death in eight young adults and one child. Three deaths occurred after surgery. Cerebrovascular accidents contributed to the cause of death in three cases and there were two sudden unexplained deaths. Ten of the deaths occurred at home or within 24 hours of admission to hospital. Post mortem examinations were made in 14 cases, but the histological appearances of acute chest syndrome were often not recognised. In most cases for whom information was available, the cause of death (chest syndrome, pneumococcal sepsis, postoperative complications) could have been prevented.
\end{abstract}

There is insufficient information available on the incidence and cause of death in patients with sickle cell disease in Britain. Some physicians still believe that the median expecyears, as calculated by Scott in 1970 from the American Bureau of Vital Statistics. ${ }^{1}$ In the United Kingdom survey of 197937 deaths in 1367 patients were reported ${ }^{2}$ : most were patients with sickle cell anaemia. Twenty five of the deaths occurred in children under 16 years of age (21 with sickle cell anaemia (SS), four with haemoglobin sickle cell disease (SC)) and 14 deaths were sudden. Mann reported five deaths (four with SS, one with SC), all sudden, in a clinic of 96 Birmingham children followed up for 10 years. ${ }^{3}$ Brozovic and Anionwu reported eight deaths from this centre in a group of 155 patients also followed up for a decade; three were sudden, two deaths were in children, six were SS. ${ }^{4}$ In

Department of Haematology, Central Middlesex Hospital, Acton Lane, London NW10

A Gray

E N Anionwu

$S$ C Davies

M Brozovic

Correspondence to:

Dr M Brozovic

Accepted for publication

10 January 1991

London nine deaths were repo of a paediatric clinic of 179 , eight of which appeared to be sudden. ${ }^{5}$ The data available pertain predominantly to children and were reported between 1975 and 1982, since when both medical and supportive care have improved.

In the Jamaican cohort study of children Rogers et al reported a mortality of $10 \%$ in the first year of life, $5 \%$ in the second, and $3 \%$ ted survival in sickle cell anaemia is only 20

in the third. ${ }^{\circ}$ A later review of patients of all ages by Thomas et al of 276 deaths in sickle cell disease over a 30 year period, of whom 241 were $S S,{ }^{7}$ suggests that at least $28.6 \%$ of the deaths in SS were sudden. Death from sickle cell disease seems most often to be related to pulmonary complications which include acute chest syndrome, infection, and pulmonary embolism. In infants under two years of age, however, the Jamaican series showed acute splenic sequestration-frequently associated with pneumococcal infection-to be marginally more common, causing 15 of the 41 deaths compared with 13 due to lung complications.

North American studies include that of Powars; 49 of 422 cases died with a $10 \%$ mortality during the first decade of life and five per cent during each subsequent decade. ${ }^{8}$ Infection was the commonest cause of death, including pneumococcal septicaemia and meningitis. The National Cooperative Study of Sickle Cell Disease in the USA showed a probability of survival to the age of 20 years of $85 \%$ for SS patients and $89 \%$ for all sickle haemoglobinopathies. Most deaths occurred in the first three years of life and were due to infection. ${ }^{9}$

We report on 18 deaths which have occurred since 1974 among a group of 384 patients on the Brent sickle cell disease register.

\section{Methods}

In 1976 a register of patients attending Central Middlesex Hospital was established ${ }^{4} ; 384$ patients have been registered (table 1 ). Of 80 patients who were on the register at some time in the past 10 years, 18 have died, 33 have been lost to follow up, 16 have gone abroad, nine have moved elsewhere in London and four out of London.

Forty four babies with sickle cell disease have been followed up from less than 3 months of age: 36 were diagnosed at birth as a result of the Central Middlesex Hospital policy of screening all births for sickle cell disease, and 11 were referred and diagnosed.

\section{Results}

CLINICAL known to have died since 1974 (table 2). Eleven were due to respiratory complications as in the Jamaican study ${ }^{7}$; nine were caused by the acute chest syndrome; one was due to pulmonary
Eighteen of the 384 patients on the register are 
Table 1 Patients with sickle cell disease on Brent register

\begin{tabular}{lllll}
\hline \multicolumn{5}{l}{ Age in years } \\
\cline { 2 - 5 } Type of sickle cell disease & $0-5$ & & \\
(No of deaths) & $\begin{array}{l}5-16 \\
\text { (No of deaths) }\end{array}$ & $\begin{array}{l}<16 \\
\text { (No of deaths) }\end{array}$ & Total \\
\hline SS & $31(2)$ & $48(3)$ & $120(8)$ & $199(13)$ \\
SC & $16(0)$ & $26(0)$ & $97(4)$ & $139(4)$ \\
Other & $5(0)$ & $8(0)$ & $33(1)$ & $46(1)$ \\
Total & $52(2)$ & $82(3)$ & $250(13)$ & $384(18)$ \\
\hline
\end{tabular}

artery thrombosis; and another to acute respiratory arrest in a severe asthmatic. Despite exchange transfusion, mechanical ventilation, and intensive resuscitation, the acute chest syndrome remains the single largest cause of death in previously well young adults with sickle cell disease.

\section{DEATHS WITHIN 24 HOURS}

Ten deaths occurred either at home or within 24 hours of admission to hospital. In the seven cases on whom detailed clinical information is available no medical treatment had been given at home. This was because patients were encouraged to contact the hospital directly and also because of the speed of onset of symptoms. Case 3 had pneumococcal septicaemia with symptoms of only a few hours duration and was sent to hospital immediately by the general practitioner. Case 5 was found dead by the GP after complaining of headaches for less than eight hours. Cases 9 and 10 who had massive pulmonary thrombosis and brain stem haemorrhage were also admitted within hours of the development of symptoms. Cases 2 and 12 were the only patients with symptoms present for longer than a few hours, but medical help had not been sought.

\section{DEATHS IN INFANTS}

Cases 1 and 2, both aged 18 months, died from acute splenic sequestration. Both had grossly enlarged spleens $(250 \mathrm{~g}$ and $200 \mathrm{~g}$, respectively). Case 2 had no pneumococcal antigen demonstrable by counterimmunoelectrophoresis in serum taken at attempted resuscitation. In case 1 pneumococcal infection could not be proved because the appropriate microbiological specimens were not taken at the coroner's postmortem examination. Neither of the two children were taking regular prophylactic penicillin: one had just arrived from Africa, and the other attended another hospital where a policy of penicillin prophylaxis had not been introduced. A third child aged 5 (case 3 ) was known not to comply with the penicillin regimen and he died with fulminant pneumococcal septicaemia; his spleen was also enlarged at $100 \mathrm{~g}$.

\section{CEREBROVASCULAR DEATHS}

Two patients died after cerebrovascular accidents: one with a massive intraventricular haemorrhage in the 38th week of pregnancy despite being treated with a prophylactic transfusion regimen (case 9); and the other after repeated strokes over a period of many years of neurological deterioration (case 13). One patient (case 17) sustained a stroke while being resuscitated from severe bilateral acute chest syndrome, while a further patient, who died from acute chest syndrome (case 11), had had a massive right sided stroke three years before death.

\section{MORTALITY RATE}

The overall mortality in our clinic is difficult to calculate accurately because some patients were lost to follow up when they moved. If all the patients on the register are included in the analysis for the years that they were followed up then the mortality in our series was one death per 128 years of follow up. The average duration of follow up was 6.7 years. Therefore one patient per clinic of 128 followed up for one year may be expected to die. Although our numbers are too small to provide reliable analysis of mortality according to age, we confirm that the mortality in the first five years of life is higher than that later in life. Of the 44 babies followed up from birth since 1981, one has been lost to follow up and two have died, giving an approximate mortality of one per 58 years of follow up for children under 5 .

\section{POSTOPERATIVE DEATHS}

Three deaths occurred postoperatively exchange transfusion had not been performed preoperatively. Case 10 had a termination of pregnancy by prostaglandin pessaries at 18 weeks of gestation followed by evacuation of the retained products of conception. She collapsed at home 27 days later and died in the ambulance on the way to hospital. The coroner's post mortem examination showed a thrombus in the right main pulmonary artery and branches of the left pulmonary artery. There was no clot in the deep veins of the calves to suggest an embolic origin and no retained products of conception, infection, or thrombosis of the vessels of the uterus to indicate a direct complication of the surgical procedure. The cause of death was given as pulmonary thrombosis.

Case 18 had a gastric carcinoma which had been resected six months previously. He had two general anaesthetics within 24 hours: the first to drain a large wound abscess caused by Streptococcus milleri following his original gastrectomy; and the second to arrest bleeding from an eroded blood vessel at which no evidence of malignant recurrence was seen. After surgery he became hypotensive, oliguric, and developed acute renal failure. The symptoms and signs of acute chest syndrome developed from which he died three days later, despite exchange transfusion and ventilation.

Case 17, a woman aged 49 , had a cervical cone biopsy performed as a day case. No malignancy was detected but she had had general malaise for about a month. This may have been due to vaginal or pelvic infection, although no outpatient treatment is recorded as having been given. She was admitted to hospital a few hours after becoming semiconscious. There was severe hypoxia with mottled lung fields on the chest $x$ ray picture and the acute sickle chest syndrome was diagnosed. Signs of 
right sided hemiplegia developed and she died on the 26th postoperative day. Bacterial cultures proved negative. The main findings of the post mortem examination were pulmonary oedema and multiple recent and old cerebral infarcts. The uterus and adnexae were normal apart from the presence of a dermoid cyst in the left ovary. There was no thrombus in the pulmonary artery and histological examination of lung tissue showed congestion and capillary dilatation in the presence of masses of sickled red cells.

\section{POST MORTEM EXAMINATIONS}

These were made in 14 out of 18 deaths, half of which were performed for coroners. These were helpful in confirming the presence of acute splenic sequestration in cases 1 and 2 . Histological examination was made in only one of the seven coroner's cases (case 3 ).

In cases 5 and 10 the main abnormalities were in the respiratory system but histological sections which might have clarified the pathogenesis were not obtained. Case 10 has already been discussed. In case 5 the lungs were described as "bulky" and as containing "very thick clot throughout the vessels", but no specific cause of death was recorded.

The eight post mortem examinations carried out in hospitals were more informative as all were cases of sickle chest syndrome and pulmonary histology was available for review. The typical macroscopic features were those of heavy, congested, and oedematous lungs. An. additional finding in case 12 was some firm thrombus adherent to the right atrium, and in case 15 bilateral pleural effusions were noted. Generally the alveolar capillaries and larger vessels were distended with masses of sickled erythrocytes associated with focal areas of microinfarction and alveolar wall necrosis. Fibrin was absent and there was a relative lack of leucocytes.

The value of careful microscopic examination is illustrated by two cases. In a limited necropsy on case 7 the expected changes were again noted, but some of the pulmonary vessels were also found to be blocked by necrotic bone marrow and thromboemboli. In the patient who died of the acute chest syndrome and had coexistent scleroderma (case 15) the atrioventricular nodal artery was obliterated by intimal fibrosis. The structure of the node itself showed no ischaemic or sclerotic changes and the rest of the heart was normal. The clinical findings of heart block progressing to asystole immediately before death may be explained by hypoxia, causing a temporary block of atrioventricular conduction and leading to cardiac arrest. It is arguable whether the obliteration of the nodal artery was the result of very early scleroderma of the heart or endothelial damage due to sickle cell disease.

\section{Discussion}

The causes of death in sickle cell disease in Britain are difficult to assess for several reasons. Firstly there is a lack of reliable information. In our study over half the deaths occurred either outside the hospital or within 24 hours of admission (table 2). Secondly, many necropsies were carried out for coroners by pathologists who seemed unaware of the complexities surrounding sudden death in sickle cell disease. Microbiological and histological samples were taken infrequently and the widespread sickling after death seen both in sickle cell disease and sickle trait are still occasionally interpreted as the cause of death. Thus despite a high proportion of necropsies, the necessary knowledge about the specific causes of death is not being gathered. Haematologists and forensic pathologists should cooperate more closely in providing training in sickle cell disease so that this important information is not lost.

Lung complications accounted for 12 of the 18 deaths in our clinic, primarily because of the acute chest syndrome. This is an area of diagnostic confusion because the term is not used to denote the same clinicopathological entity by all authorities. In the United Kingdom the term is generally reserved for cases of acute pulmonary failure where no infective cause is found or where any infective component is considered to be minor or remote from

Table 2 Causes of death in 18 patients with sickle cell disease

\begin{tabular}{|c|c|c|c|c|c|c|}
\hline $\begin{array}{l}\text { Case } \\
\text { No }\end{array}$ & $\begin{array}{l}\text { Sickle cell } \\
\text { disease/age } \\
\text { in years }\end{array}$ & $\begin{array}{l}\text { Duration of } \\
\text { symptoms before } \\
\text { admission }\end{array}$ & $\begin{array}{l}\text { Duration of } \\
\text { last admisison }\end{array}$ & Causes of death & Post mortem & Comment \\
\hline $\begin{array}{l}1 \\
2 \\
3 \\
4 \\
5 \\
6 \\
7 \\
8 \\
9\end{array}$ & $\begin{array}{l}S S / 1 \cdot 5 \\
S S / 1 \cdot 5 \\
S S / 5 \\
S S / 9 \\
S S / 15 \\
S S / 15 \\
S S / 18 \\
S S / 19 \\
S \text { beta- } \\
\text { thallassaemia/19 }\end{array}$ & $\begin{array}{l}2 \text { days } \\
<6 \text { hours } \\
4 \text { days } \\
<8 \text { hours } \\
5 \text { days } \\
5 \text { days } \\
-\end{array}$ & $\begin{array}{l}\text { Dead on arrival } \\
\text { Dead on arrival } \\
6 \text { hours } \\
3 \text { days } \\
\text { Dead on arrival } \\
27 \text { hours } \\
5 \text { days } \\
\text { Dead on arrival } \\
\text { Dead on arrival }\end{array}$ & $\begin{array}{l}\text { ASS } \\
\text { ASS } \\
\text { Pneumococcal septicaemia } \\
\text { Chest syndrome } \\
\text { Unknown } \\
\text { Chest syndrome } \\
\text { Chest syndrome } \\
\text { Respiratory arrest } \\
\text { CVA }\end{array}$ & $\begin{array}{l}\text { Coroner's } \\
\text { Coroner's } \\
\text { Coroner's } \\
\text { Hospital } \\
\text { Coroner's } \\
\text { None } \\
\text { Hospital } \\
\text { Coroner's } \\
\text { Coroner's }\end{array}$ & $\begin{array}{l}\text { No antibiotic prophylaxis } \\
\text { No antibiotic prophylaxis } \\
\text { No antibiotic prophylaxis } \\
\text { Found dead in bed on ward } \\
\text { Found dead at home } \\
\text { Severe asthma } \\
38 \text { weeks pregnant- } \\
\text { transfused }\end{array}$ \\
\hline $\begin{array}{l}10 \\
11 \\
12 \\
13 \\
14 \\
15 \\
16 \\
17 \\
18\end{array}$ & $\begin{array}{l}S S / 19 \\
S S / 19 \\
S S / 21 \\
S S / 26 \\
S C / 27 \\
S C / 28 \\
S S / 32 \\
S C / 49 \\
S C / 54\end{array}$ & $\begin{array}{l}<12 \text { hours } \\
1 \text { hour } \\
9 \text { hours } \\
<3 \text { hours } \\
-\quad 12 \text { hours } \\
-\quad 28 \text { days } \\
28 \text { days }\end{array}$ & $\begin{array}{l}\text { Dead on arrival } \\
<12 \text { hours } \\
24 \text { hours } \\
10 \text { days } \\
\text { Dead on arrival } \\
36 \text { hours } \\
3 \text { days } \\
5 \text { days } \\
5 \text { days }\end{array}$ & $\begin{array}{l}\text { Pulmonary artery thrombosis } \\
\text { Chest syndrome } \\
\text { Chest syndrome } \\
\text { CVA } \\
\text { Unknown } \\
\text { Chest syndrome } \\
\text { Chest syndrome } \\
\text { Chest syndrome } \\
\text { Chest syndrome and renal } \\
\text { failure }\end{array}$ & $\begin{array}{l}\text { Coroner's } \\
\text { Hospital } \\
\text { Hospital } \\
\text { None } \\
\text { ? } \\
\text { Hospital } \\
\text { Hospital } \\
\text { Hospital } \\
\text { Hospital }\end{array}$ & $\begin{array}{l}\text { Found dead } \\
\text { Scleroderma } \\
26 \text { days postoperatively } \\
3 \text { days postoperatively }\end{array}$ \\
\hline
\end{tabular}


the lungs. ${ }^{10}$ On the other hand, the reports from Jamaica do not distinguish those cases related to pneumonia from those attributed to pulmonary embolism. ${ }^{7}$

A further source of controversy surrounds the pathogenesis of acute chest syndrome. While most authors agree that most cases are caused by ischaemic infarcts, opinions on the contribution of pulmonary embolism vary. Oppenheimer and Esterly found necropsy evidence of thromboemboli in nearly $66 \%$ of patients with sickle cell disease, noting that the prevalence increased with age. ${ }^{11}$ Haupt et al, however, found no significant difference in the prevalence of thromboemboli and thromboembolic infarction among 72 patients with sickle cell disease and age, sex, and racematched controls. ${ }^{12}$ Instead, massive pulmonary emboli of necrotic bone marrow were reported in nine $(13 \%)$ patients but not in controls. There was also an increased incidence of alveolar wall necrosis ( $17 \%$ compared with $6 \%$ ).

Embolism of thrombus or necrotic bone marrow may not be the only cause of pulmonary infarction. In a careful histological examination of a single case of the acute chest syndrome Athanasou et al found multiple large pulmonary infarcts, ${ }^{13}$ most of which had no association with thrombosis or emboli. Vascular spasm was suggested as an alternative mechanism of infarction.

In all of these studies of the acute chest syndrome the most consistent finding is the presence of intense arteriolar and capillary congestion with masses of sickled red cells. This also features in the present series but is often described as non-specific and mistakenly attributed to sickling after death or left ventricular failure. These changes were not seen in our evaluable non-pulmonary deaths (cases 2 and 3 ) where the lungs remained well aerated. We regard them as specific for acute chest syndrome, whatever its aetiology. As case 7 of the present study shows it is possible for this basic histological background to have the particular features reported in previous studies, suggesting that a mixture of pathogenetic processes can interact, with one or other predominating in an individual case.

In a situation where there is still so much debate on the precise cause of the acute chest syndrome, it is vital that careful post mortem examinations are performed so that appropriate clinical-pathological correlations can be made.

A high level of clinical suspicion, early recognition, and aggressive treatment of this complication may well reduce the resulting deaths. We consider careful monitoring of the patients with sickle cell disease, including arterial blood gas analysis, to be essential to start timely exchange transfusion and assisted ventilation. ${ }^{14}$

In 1979 only $24 \%$ of United Kingdom centres reported prescribing prophylactic penicillin, ${ }^{2}$ but by 1986 the American National Cooperative Study reported three deaths from pneumococcal sepsis in 110 children taking placebo and no deaths in the 105 children taking twice daily oral penicillin. ${ }^{15}$ Deaths related to sepsis should be avoidable, in particular those due to pneumococcal infection which has also been implicated in the aetiology of acute splenic sequestration crisis. In case 3 the mother was repeatedly urged to comply with the treatment but despite counselling she was insistent that her son only required prophylaxis during the autumn and winter months. Routine vaccination against Streptococcus pneumoniae should be considered for these children.

Of three postoperative deaths, one occurred in a patient with resected gastric carcinoma who developed a wound abscess, gastrointestinal bleeding, and acute renal failure. Arguably this death, due to the acute chest syndrome, might have been avoided had he been electively exchange-transfused. Two deaths occurred in the fourth week after gynaecological procedures. No pelvic pathology was evident at post mortem examination, but both deaths were from pulmonary causesnamely, pulmonary artery thrombosis and the acute chest syndrome. Anaesthesia and surgery were therefore not the immediate cause of death. In view of the possible thromboembolic aetiology of both conditions, however, the question arises whether such a process began at the time of surgery and whether prophylactic subcutaneous heparin (which neither patient received) would have been beneficial. Our practice has now been amended to include this measure.

Mortality can only be reliably assessed through a study of a cohort of children with sickle cell disease followed up from birth, as has been elegantly shown by Serjeant in Jamaica. ${ }^{67}$ In Britain few district health authorities have adopted neonatal screening programmes for sickle haemoglobinopathies. The screening in Brent was started in 1981 and a regional programme is now being introduced for all births in the North West Thames Region. Even with the whole region systematically screened only about 25 babies with sickle cell disease are likely to be born every year-a number too small to provide reliable mortality figures in the short term. A cooperative study of all babies diagnosed at birth in Britain and the more widespread acceptance of neonatal screening would help to clarify the situation more rapidly. A further argument for such a policy is that a high proportion of children with sickle cell disease die with the initial symptoms of their disease. ${ }^{16}$ If not screened at birth these children will not be diagnosed and their deaths will be unavoidable.

The cause of death was evaluable in 16 of our 18 cases. One death (case 9) may not have been preventable, but in almost all of the remaining cases death might have been prevented by improved antibiotic prophylaxis, perioperative care, and earlier intervention, even though 10 of the 18 cases died at home. The Cooperative Study of Sickle Cell Disease in the USA showed a $3.3 \%$ infant death rate in 600 such children enrolled before 6 months of age. ${ }^{17}$ This is lower than the previously reported mortality and is accounted for by early diagnosis of sickle 
cell disease, successful treatment of pneumococcal septicaemia, immunisation, and improved nutrition, education and health care. ${ }^{18}$

The importance of continuing education of patients and their families as well as medical and nursing staff cannot be over-emphasised. As no major innovations can be seen in the management of sickle cell disease early diagnosis and the identification of preventable causes of death remain the most likely means of reducing the death rate in this disease.

1 Scott RB. Health care priority and sickle cell anaemia. JAMA 1970;214:731-4.

2 Davis LR, Huehns ER, White JM. Survey of sickle cell disease in England and $W$ ales. Br Med $J 181 ; 283: 1519-21$.

3 Mann JR. Sickle cell haemoglobinopathies in England. Arch Dis Child 1981;56:676-83.

4 Brozovic M, Anionwu EN. Sickle cell disease in Britain. J Clin Pathol 1984;37:1321-6.

5 Murtaza NL, Stroud CE, Davies LR, Cooper DJ. Admissions to hospital of children with sickle cell anaemia: study in South London. Br Med J 1981;282:1048-52.

6 Rogers DW, Clarke JM, Cupidore L, Ramial AM, Sparke
BR, Serieant GR. Early deaths in Jamaican children with sickle cell disease. Br Med J 1978;i:1515-6.

7 Thomas AN, Pattison C, Serjeant GR. Causes of death in sickle cell disease in Jamaica. $\mathrm{Br}$ Med J 1982;285:633-5.

8 Powars DR. Natural history of sickle cell disease-the first ten years. Semin Hematol 1975;12:267-85.

9 Leikin SL, Gallagher D, Kinney TR, Sloane D, Klug P. Rida W, and the Cooperative Study of Sickle Cell Disease. Mortality in children with sickle cell disease. Paediatrics Mortality in chidr.

10 Davies SC, Brozovic $M$. The presentation, management and prophylaxis of sickle cell disease. Blood Rev 1989;3:29-44. 11 Oppenheimer EH, Esterly JR. Pulmonary changes in sickle cell disease. Am Rev Respir Dis 1971;103:858.

12 Haupt HM, Moore GW, Bauer TW, Hutchins GM. The lung in sickle cell disease. Chest 1982;81:332-6.

13 Athanasou NA, Hatton C, McGee J O'D, Weatherall DJ. Vascular occlusion and infarction in sickle cell crisis and the sickle chest syndrome. J Clin Pathol 1985;38:659-64.

14 Davies SC.. The management of acute emergencies in sickle cell disease. In: London: Ballière Tindall 1989.

15 Gaston MH, Verter JI, Woods G, et al. Prophylaxis with oral penicillin in children with sickle cell anaemia. $N$ Engl J penicillin in children

16 Lobel JS, Cameron B, Johnson E, Smith D, Kalinyak K. Value of screening umbilical cord blood for haemoglobinopathy. Pediatrics 1989;83:823-6.

17 Gill FM, Brown A, Gallagher D, et al. Newborn experience in the Co-operative Study of Sickle Cell Disease. Paediatrics 1989;83:827-9.

18 Powars D, Overturf G, Weiss J. Pneumococcal septicaemia in children with sickle cell anaemia: changing trend of survival. JAMA 1981;245:1839-42. 